\title{
Front-line work in employment services after ten years of new public management reform: Governance and activation in Australia, the Netherlands and the UK
}

MARK CONSIDINE, School of Social and Political Sciences, University of Melbourne

JENNY M. LEWIS, School of Social and Political Sciences, University of Melbourne Accepted for publication in European Journal of Social Security (SAGE, 2010)

\begin{abstract}
This study examines the impact of administrative reforms upon the work of front-line staff in the employment services of three reform-oriented countries - Australia, the Netherlands and the United Kingdom. These changes have involved greater use of private agents, more detailed performance contracts, clearer expectations about outcomes for job-seekers, and increased competition between agencies seeking government work. The study compares the work characteristics and strategies of front-line staff in agencies in the three systems in 2008 and a decade earlier, using surveys.
\end{abstract}

The results show that there are substantial differences in the level of tailoring and investment in these countries. There are three relatively stable modes of governance in these cases and the most stable of these types across countries and across time is what we term the corporatemarket mode - more generally labelled New Public Management (NPM). Despite the expectations of theorists and of reformers, the role of network governance proves neither as stable nor as generalised as expected.

Keywords: contracting-out; governance; new public management; street level bureaucracy; unemployment 


\section{INTRODUCTION}

Over the past ten years or so, there has been a sea-change in the way public services for jobseekers are imagined and enacted. Most of this new thinking and the instruments it has sponsored can be seen as a new set of relationships at the front-line of service delivery. Rather than simply being seen as the distribution point for programmes and entitlements, front-line staff are now viewed as enacting a programme logic of their own. This is widely understood to involve various kinds of activation (Van Berkel and Van der Aa 2005). In place of traditional bureaucratic instruments based upon norms of standardised treatment and universal service, we see a trend towards output targets, quasi-market contracting and efforts to engage employers and other users in service delivery. A significant part of this effort is devoted to changing the relationships at the front-line to make both staff and job-seekers more responsive to policy goals by acting with greater flexibility and with a more determined focus upon defined outcomes (Barbier and Ludwig-Mayerhofer 2004).

Helping drive these changes is a normative and pragmatic shift in government policy to 'principal-agent' relations in such services (Sol and Hoogtanders 2005). For the purposes of this article we will define these changes as New Public Management (NPM). The logic of NPM was largely concerned with adopting techniques of planning and budgeting from private-sector companies and conglomerates in the 1970s and 1980s, and then, by the late 1980s and early 1990s, some countries used privatisation and contracting-out as a means of shifting the burden of administration and management to qualified agents from the for-profit and non-profit sectors. NPM is generally seen as combining earlier 'corporate management' innovations such as expanded management discretion and performance-based pay regimes, with quasi- market instruments such as purchaser-provider splits, and competitive tendering for services.

In the employment services field Australia helped pioneer a number of these innovations in relation to public employment services, ultimately turning most service delivery functions over to non-profit and for-profit firms to run. Other public systems around the world, including those in the UK and the Netherlands, have also contracted parts of these services out to private providers over the past ten years, increased their use of performance contracts and targets, and placed stronger emphasis on integrating services for job-seekers with the needs of local labour markets and employers. 
The new service delivery environments created by these various NPM reforms place different kinds of demands on governments compared with traditional bureaucratic services. On the front-line there is a greater commitment to tailoring services to the individual needs of jobseekers and employers. At an organisational level, this is also a more complex environment for government leaders as they seek to steer using tools that are often more exacting but also more remote from the front-line. Compared to a bureaucratic agency controlled from above and managed on a day-to-day basis, in the NPM world the minister and chief executive must embed policy into tender specifications and contracts which run for several years and may only be changed in exceptional circumstances. On the other hand they can more easily reward and punish those who act as their agents than was the case in a heavily regulated public service context.

In this paper we examine the impact of reforms on employment services on the front-line, in relation to the stability of governance modes over time and between countries. Our selection of Australia, the UK and the Netherlands as cases for empirical review is based upon their roles as leading exponents of reform in these areas. In each of these countries there is a substantial record of change over the past ten years upon which to base an empirical analysis of the impact of NPM changes. Other countries have also engaged in such reform in recent years, with Denmark and Germany greatly expanding the role of contractors and increasing the use of performance-based instruments in the past five years. But in our three cases there is a record of reform that covers a longer period, and there is therefore a higher probability that we can examine the impact on front-line services, rather than simply comparing policy reform narratives by governments and academics - an all too common problem with the NPM debate more broadly.

\section{NPM IN COMPARATIVE PERSPECTIVE}

Although there is a considerable literature on new public management, there is less agreement upon its precise meaning and origins. While Hood (1991) is sometimes credited with coining the term, the debate about managerialism actually emerged in the 1980s, and authors like Pollitt (1990), Considine and Painter (1987), and Gregory (1995) had, by this stage, drawn a clear distinction between traditional bureucratic norms and the practices and 
promises of new management-centred reforms. This first new broom swept through areas such as corporate planning, the introduction of performance measurement at programme level, and the development of a different kind of executive class (senior executive service etc.) inside the public service. These were often American innovations and they typically came via the Carter Government's experiments with programme budgeting and the other financial management reforms associated with its innovative if flawed Office of Management and Budget.

Other academic treatments of the emergence of NPM begin the story with the Reagan and Thatcher governments and argue that these were in effect, neo-liberal reforms (Boston et al. 1996) owing a direct debt to Friedmanite critiques of public budgeting and public choice attacks on the effects of public programmes (Christensen and Lægreid 2001). This debate about the genesis and meaning of NPM points us to the fact that the term describes a number of related but different reform traditions. In applying these to the study of employment services, we have identified a basic bureaucratic tradition, plus two reform trajectories corporate-market, and a more recent network (or 'joined up') governance type. It will be obvious that corporate- market governance is close to the academic description of NPM as it is identified in the literature.

We sought to examine the three national systems from the perspective of possible different modes of governance using multivariate analysis. A decade ago, in relation to employment services, we first postulated that there were four identifiable governance modes (ideal types) with different characteristics - procedural, corporate, market and network (Considine and Lewis 1999). These were seen as having distinct attributes in relation to their key rationalities, forms of control, primary virtues and service delivery focus. The easiest way to contrast them is in relation to their forms of control: The procedural type rests on rules, the corporate type on plans, market on contracts, and network on co-production. However, when these conceptual types were tested empirically, only three distinct modes emerged, with the corporate and market types combining to form a single, integrated mode, based on a hybrid of management and competition. This fits well with academic descriptions of NPM. A more detailed discussion of these types can be found in our earlier work (Considine and Lewis 1999, 2003; Considine 2001). 
The network form was the most speculative of the types a decade ago, given the novelty of this form of organisation, compared with traditional procedural bureaucracy and NPM ideas (Considine and Lewis 2003), the (not always helpful) positive gloss that often accompanies a discussion of networks, joined-up government and collaborative approaches to service delivery (Lewis 2005), and the lack of robust descriptions of how this actually functions as a form of management (Kickert, Klijn and Koppenjan 1997).

From 1996-99 (referred to from hereon in as the 1998 study), front-line employment services staff in the UK, Australia, New Zealand and the Netherlands were surveyed, with a focus on examining the understandings these staff have of how they do their work. In 2008 the same survey with only minimal wording changes was conducted again. Around 100 questions were included in this survey in total. The earlier survey was paper based, while the more recent one was conducted online. Staff were eligible to complete the survey if they had any contact with job-seekers. The number of respondents for each year and country is provided in Table 1.

Table 1: Number of survey respondents in 1998 and 2008

\begin{tabular}{|l|l|l|l|}
\hline & $\mathbf{1 9 9 8}$ & $\mathbf{2 0 0 8}$ & Total \\
\hline Australia & 625 & 1512 & 2137 \\
The Netherlands & 274 & 914 & 1188 \\
UK & 155 & 1196 & 1351 \\
\hline Total & 1054 & 3622 & 4676 \\
\hline
\end{tabular}

\section{FRONT-LINE WORK}

The promises of NPM reforms in this policy field in each of these countries have had some common themes over the ten years. They have each sought greater tailoring of services to the needs of clients, the use of contestability and competition to drive greater efficiency in service delivery, 'activation' of both staff and clients through the use of a 'carrots and sticks' regime of payments and sanctions, and improved links to local labour markets and the needs of local employers. 
What emerges from the comparative data in Table 2 is somewhat different. Starting with Australia, the most market-oriented of the three, we see front-line work becoming less flexible and less likley to be tailored to the individual needs of clients. This is evidenced by high caseloads and a very high number of clients seen each day compared to the two other countries. In the first study the Australians were interviewing about 8 job-seekers in an average day, and ten years later this had risen to more than 10 , on average. The work with job-seekers took about half the time of staff ten years earlier, but had dropped to 45 per cent of time in the second study. Australian staff were likely to be younger and female compared with the earlier cohort and compared with those in other countries. Both union membership and work satisfaction had decreased significantly in Australia over this ten-year period. None of this appears consistent with the idea that work at the front-line would become a more sophisticated form of tailoring to the needs of clients, better equipped to address very different individual and local conditions. This is further supported by data on the overall levels of spending in Australia and other OECD countries with recent studies showing that, for the 2008-9 period, Australia spent 0.01 percent of GDP on support programmes, while the OECD average was 0.14 percent. In other words, the Australian case indicates higher efficiency but also lower investment (OECD 2010).

In the UK these data show caseloads rising but the number seen each day declining, evidence of greater attention being given to those who do come for interview. And while there has been a decline in how much of the job is devoted to working directly with job-seekers, the figure is substantially higher than for Australia, indicating that other issues such as paperwork and compliance monitoring have not intervened in quite the way they have in Australia. Work satisifaction increased significantly during this period, also reinforcing the impression that work at the front-line was improved by the policy changes enacted. The UK workforce had become older, the percentage of females had fallen slightly, and union membership has fallen, but not as drastically as in Australia.

In the Netherlands the workforce became somewhat older and the gender balance improved, suggesting that front-line work became more attractive to workers with stronger labour market opportunities. We cannot say whether this was only a result of privatisation but it does seem likely that, because the Dutch firms entering this sector were more likely to be forprofit companies than was the case in Australia and the UK, they were more likely to bring with them a cohort of male staff with significant experience in the recruitment and related 
employment services industries. There is no evidence to suggest that this was a deliberate design commitment by the Dutch policy makers responsible for NPM reforms, although the preference they showed for contracts with heavy loadings on 'no cure, no pay' forms of performance reward may well have acted as an informal deterrent to the entry of the kinds of NGOs found in the other two countries where such risks were moderated by contracts with upfront payments. Work satisfaction and union membership have remained fairly stable in the Netherlands.

The other striking aspect of the Dutch case is the decline in caseloads. Since we know that the Dutch firms have demanding performance contracts, we can assume that the lower number of clients on each person's list means greater attention to each individual. This would be consistent with data showing that the Netherlands is in the higher bracket of OECD countries when it comes to spending on training and other skill development, including spending on the unemployed (OECD 2010).

Table 2: Comparing Front-Line Work Characteristics

\begin{tabular}{|l|l|l|l|l|l|l|}
\hline \multirow{2}{*}{} & \multicolumn{2}{|c|}{ Australia } & \multicolumn{2}{c|}{ UK } & \multicolumn{2}{c|}{ The Netherlands } \\
\cline { 2 - 7 } & 1998 & 2008 & 1998 & 2008 & 1998 & 2008 \\
\hline Female staff & 61.8 & 73.8 & 70.3 & 68.2 & 65.4 & 56.8 \\
Staff under 34 years (\%) & 28.5 & 42.3 & 39.3 & 32.2 & 64.7 & 21.6 \\
Union members (\%) & 44.2 & 6.8 & 61.4 & 39.5 & $26.6 \mathrm{a}$ & 23.7 \\
Caseload/FTE & 118.7 & 97 & 46.3 & 58 & 87.2 & 75.4 \\
Number per day & 8.4 & 10.3 & 10.1 & 8.4 & 10.1 & 4.8 \\
Time with job-seekers (\%) & 50.1 & 45.7 & 72.9 & 59.7 & 37.3 & $39.7 \mathrm{~b}$ \\
Work Satisfied (\%)c & 61.3 & 49.2 & 23.3 & 50.5 & 59.3 & 57.5 \\
\hline
\end{tabular}

Notes:

1. Only 37 per cent of public officials were in a union and only 12 per cent of those surveyed in the private agencies were unionised, suggesting one reason why experiments with contracting might have been possible in this sector rather than others.

2. The Dutch survey had more options in 2008, making exact comparisons with the other countries harder.

3. The question asked was: 'To what extent are you satisfied with your present conditions of work (pay, hours, promotion etc)?' 


\section{NPM AND GOVERNANCE REGIMES}

As reported earlier in this paper, the initial Australian study found three coherent factors through an exploratory factor analysis and reliability analysis, and these three factors appeared again and achieved a reasonable goodness-of-fit using confirmatory factor analysis on the full data set (Considine and Lewis 2003). We focus on the three factor solutions again in this paper, however, factor analysis was undertaken for the three countries separately, in order to examine system differences. As in the earlier study, principal components analysis with varimax (orthogonal) rotation was used to extract the factors. The factor loading from the three factor solutions for each country in both survey periods, can be found in the Appendix. Scree plots of the eigenvalues for these factor analyses indicate that 3,4 and 5 factor solutions are worth examining. Only the 3 factor solutions have been examined, as the main interest is in determining stability in relation to the earlier results.

It is important to note at the outset that the three factors do approximate the original governance types from the earlier study. This points to some enduring features of the frontline realities of the three case countries. In addition, the analysis shows some variations for the composition of the corporate-market, network and procedural types and we turn now to this examination of stability and change in governance on the front-line.

To assess the stability of the three governance types from the earlier study, we compared the level of correspondence ofthe results from each of the factor analyses in 1998 and 2008 with the factors obtained originally. This is shown in Table 3, where the number of items on the scales in the 1998 study are shown (10 for corporate-market, 6 for network and 7 for procedural) in the first row. These are followed by the number of items from the factors for each country in each time period, which correspond to those in the original all-countries factors, plus any additional items that load on that factor (indicated after the + signs in the table).

The corporate-market type has the most consistency in each country and time period. It had 10 items in the earlier combined study and the items load on the same dimension for both countries in 7 cases for Australia and the Netherlands and 8 for the UK in 1998, and 7 for the Netherlands and 9 for both Australia and the UK in 2008. Only a small number of additional 
items loaded onto this type, varying from zero to 3 . In other words, there is a high degree of stability over time and between countries for this core NPM type. 
Table 3: Correspondence between original and factors

\begin{tabular}{|l|l|l|l|}
\hline & Corporate-market & Network & Procedural \\
\hline All countries 1998 & 10 & 6 & 7 \\
\hline Australia 1998 & $7+1$ & $4+3$ & $4+3$ \\
The Netherlands 1998 & $7+3$ & $2+6$ & $2+5$ \\
UK 1998 & $8+2$ & $4+3$ & $5+4$ \\
Australia 2008 & $9+1$ & $5+3$ & $5+2$ \\
Netherlands 2008 & $7+1$ & $4+6$ & $3+3$ \\
UK 2008 & $9+0$ & $6+7$ & $4+1$ \\
\hline
\end{tabular}

The procedural type is the next most stable, with between 2 and 5 of the original 7 items appearing on each. However, the Dutch case in both time periods is the most different, with only 2 of the same items in 1998 and 3 in 2008. More different items are present in 1998 for the Netherlands (5) and the UK (4). One explanation for this is the much larger number of Australian staff, compared to the other countries, included in the first study. This would weight the original factors towards the Australian case. Network governance has an even smaller core set of items that remain stable, and a greater number of different items appear, especially in the Dutch case in both studies (6) and the UK in 2008 (7). These findings make the relative consistency of the corporate-market type more interesting, and indicate that this type transcends national regime and time period boundaries in a way that the other two do not.

This analysis also provides some provocative evidence that a network governance orientation is the most context (regime and time period) specific. While the meaning of the procedural type also changes across cases, this is clearly more stable in 2008 than the network type. This finding suggests that either system or environmental changes have led to a greater concentration on corporate-market and procedural governance in 2008. A less settled definition of network governance is apparent in all three countries. We speculate that the network type may be popular as a transitional strategy for dealing with large institutional 
change, and so its meaning shifts more than the other types as people search and find strategies to meet the new demands of their work.

\section{CONCLUSIONS}

This paper has examined work practices and governance types on the front-line of employment service provision, whether these are similar for advisers in different countries delivering a similar service, and whether they remain stable over time as systems are reformed.

The use of evidence collected from front-line staff enabled us to examine differences in work practices between regimes, and to determine that there are stable modes of governance that can be observed across time and between different systems. It clearly indicates that not all modes of governance remain as stable as others, and that the corporate -market or NPM type is easily the most resilient across these three countries and over the decade.

A descriptive analysis of the work chararcteristics of those on the front-line yielded some insights into how the make up of those doing this work has changed in each country, often in contrast to the expectations that accompany notions of greater tailoring of services. We also found this varied substantially between the three countries, with Australia standing out as the system with the least discretion, at least in terms of some basic characteristics of the work that front-line staff are doing. Second, we found that the three different modes of governance identified in our previous work could also be observed to varying extents in different contexts and different time periods. This suggests that we are able to regard such governance types as a viable method for distinguishing between systems and time periods.

Third, the most stable of these types was corporate -market, which had the highest level of correspondence with the original all-country study of governance ideal-types. This appears to reflect a form of stability in the intentions and signals provided by governments in different countries and at different time periods, that mirror NPM ideas. The procedural and network types were less stable, and in particular, the network type varied substantially from context to context. This indicates that the network type is more fluid and less coherent than the other more established modes of governance. Despite the fact that network governance has been a substantial field of research for two decades, it is harder to pin down in conceptual terms and 
also less clearly something that is concrete and identifiable to those working on the front-line of service delivery. Certainly we can conclude that there is no clear and identifiable trend towards this as a type of action or method of organisation in the minds of these front-line staff. The analysis suggests that networking might represent a particular strategy for dealing with large system changes, rising in times of upheaval and then falling once these changes become established.

Finally we conclude that the capacity for signals to reinforce a common approach varies between the three cases. The Netherlands, with its more complex decision making process than Australia and the UK across the ten years, stands out from them, both in terms of its workforce characteristics, and also in relation to the stability of the governance types. The Australian case displays the least evidence of tailoring of services, and while both of the other countries were making greater investments in unemployment services which can be seen on the front-line in terms of who they are and what their workloads are like, Australia lagged behind. NPM is without doubt shaping employment services in each of these three countries. But there is more variation in front-line governance types in the Netherlands than there is elsewhere. 


\section{References}

BARBIER, J.-C. and LUDWIG-MAYERHOFER, W. (2004) 'Introduction: The many worlds of activation', European Societies, 6(4), 423-436.

CHRISTENSEN, T. and LÆGREID, P. (2001) New Public Management: The Transformation of Ideas and Practice, Aldershot, Ashgate.

CONSIDINE, M. (2001) Enterprising States: The public management of welfare-to-work, Cambridge, Cambridge University Press.

CONSIDINE, M. and PAINTER, M. (eds.) (1987) Managerialism: The Great Debate, Melbourne, Melbourne University Press.

CONSIDINE, M. and LEWIS, J.M. (1999) 'Governance at ground level: The front-line bureaucrat in the age of markets and networks', Public Administration Review, 59(6), 467480.

CONSIDINE, M. and LEWIS, J.M. (2003) 'Bureaucracy, network or enterprise? Comparing models of governance in Australia, Britain, the Netherlands and New Zealand', Public Administration Review, 63(2), 131-140.

GREGORY, R. (1995) 'The Peculiar Tasks of Public Management: Towards Conceptual Discrimination', Australian Journal of Public Administration, 54(2), 171-183.

HOOD, C. (1991). 'A Public Management for all Seasons'. Public Administration, 69(1), 319.

KICKERT, W., KLIJN, E.H. and KOPPENJAN, J. (eds.) (1997) Managing Complex Networks: Strategies for the Public Sector, London, Sage.

LEWIS, J.M. (2005) Health Policy and Politics: Networks, Ideas and Power, Melbourne, IP Communications.

OECD (2010) Employment Outlook, Paris.

POLLITT, C. (1990) Managerialism and the Public Services: The Anglo-American Experience Oxford and Cambridge, MA, Blackwell.

SOL, E. and HOOGTANDERS, Y. (2005) 'Steering by Contract in the Netherlands: 
New Approaches to labour Market Integration' in Sol, E. and Westerveld, M. (eds)

Contractualism in Employments Services: A New Form of Welfare State Governance, The Hague, Kluwer Law International, 139-166.

VANBERKEL, R.and VANDERAA, P. (2005), 'The marketization of activation services: a modern panacea? Some lessons from the Dutch experience', Journal of European Social Policy, 15(4), 329-343. 


\section{Appendix 1: 1998 Factor Loadings for 3 Factor Solution}

\begin{tabular}{|c|c|c|c|c|c|c|c|c|c|}
\hline & \multicolumn{3}{|c|}{$\begin{array}{c}\text { Australia } \\
\text { (24.5\% of variance explained) }\end{array}$} & \multicolumn{3}{|c|}{$\begin{array}{c}\text { The Netherlands } \\
\text { (23.0\% of variance explained) }\end{array}$} & \multicolumn{3}{|c|}{$\begin{array}{c}\text { UK } \\
\text { (27.2\% of variance explained) }\end{array}$} \\
\hline & $\begin{array}{l}\text { Corporate- } \\
\text { market }\end{array}$ & Network & Procedural & $\begin{array}{l}\text { Corporate- } \\
\text { market }\end{array}$ & Network & Procedural & $\begin{array}{l}\text { Corporate- } \\
\text { market }\end{array}$ & Network & Procedural \\
\hline $\begin{array}{l}\text { 1. I find that issuing } \\
\text { Participation Reports } \\
\text { (sanctions) can really } \\
\text { damage your } \\
\text { reputation with job } \\
\text { seekers and others in } \\
\text { the employment field }\end{array}$ & & & & & & .53 & .32 & & \\
\hline $\begin{array}{l}\text { 2. The lines of authority } \\
\text { are not clear in my } \\
\text { work }\end{array}$ & .38 & & -.48 & & .48 & & .49 & & -.38 \\
\hline $\begin{array}{l}\text { 3. I do not like my } \\
\text { competition (internal } \\
\text { or external) to know } \\
\text { how I go about } \\
\text { getting my results }\end{array}$ & .40 & & & & .56 & & -.33 & & \\
\hline $\begin{array}{l}\text { 4. My job can be done } \\
\text { by following a few } \\
\text { basic rules }\end{array}$ & & & & & & .41 & & .31 & -.36 \\
\hline $\begin{array}{l}\text { 5. When it comes to } \\
\text { day-to-day work I am } \\
\text { free to decide for } \\
\text { myself what I will do } \\
\text { with each job seeker }\end{array}$ & & & & & .36 & & & .46 & \\
\hline
\end{tabular}




\begin{tabular}{|c|c|c|c|c|c|c|c|c|c|}
\hline & \multicolumn{3}{|c|}{$\begin{array}{c}\text { Australia } \\
\text { (24.5\% of variance explained) }\end{array}$} & \multicolumn{3}{|c|}{$\begin{array}{c}\text { The Netherlands } \\
\text { (23.0\% of variance explained) }\end{array}$} & \multicolumn{3}{|c|}{$\begin{array}{c}\text { UK } \\
\text { (27.2\% of variance explained) }\end{array}$} \\
\hline & $\begin{array}{l}\text { Corporate- } \\
\text { market }\end{array}$ & Network & Procedural & $\begin{array}{l}\text { Corporate- } \\
\text { market }\end{array}$ & Network & Procedural & $\begin{array}{l}\text { Corporate- } \\
\text { market }\end{array}$ & Network & Procedural \\
\hline $\begin{array}{l}\text { 6. My supervisor knows } \\
\text { a lot about the work I } \\
\text { do day-to-day }\end{array}$ & & & .66 & & & & -.32 & & .55 \\
\hline $\begin{array}{l}\text { 7. The really important } \\
\text { rules in this job are } \\
\text { the ones to do with } \\
\text { obtaining assistance } \\
\text { from other } \\
\text { organisations }\end{array}$ & .50 & .42 & & .45 & & & & .37 & \\
\hline $\begin{array}{ll}\text { 8. } & \text { In my job, I am NOT } \\
\text { influenced by } \\
\text { numerical targets } \\
\text { (including star rating) }\end{array}$ & -.45 & & & & -.56 & & -.34 & .42 & \\
\hline $\begin{array}{l}\text { 9. The main thing I have } \\
\text { to do in this job is } \\
\text { gain the trust of the } \\
\text { job seeker }\end{array}$ & & .51 & & .32 & & & & .61 & \\
\hline $\begin{array}{l}\text { 10. Our organisation has } \\
\text { targets for certain } \\
\text { types of job seekers }\end{array}$ & .41 & & & .34 & & & .38 & & \\
\hline $\begin{array}{l}\text { 11. When I come across } \\
\text { something not } \\
\text { covered by the } \\
\text { procedural guide, I } \\
\text { refer it to my } \\
\text { supervisor }\end{array}$ & & & .63 & .32 & & .44 & & & .46 \\
\hline $\begin{array}{l}\text { 12. The goal in this work } \\
\text { is to find a middle }\end{array}$ & & & & & & .47 & & & .33 \\
\hline
\end{tabular}




\begin{tabular}{|c|c|c|c|c|c|c|c|c|c|}
\hline & \multicolumn{3}{|c|}{$\begin{array}{c}\text { Australia } \\
\text { (24.5\% of variance explained) }\end{array}$} & \multicolumn{3}{|c|}{$\begin{array}{c}\text { The Netherlands } \\
\text { (23.0\% of variance explained) }\end{array}$} & \multicolumn{3}{|c|}{$\begin{array}{c}\text { UK } \\
\text { (27.2\% of variance explained) }\end{array}$} \\
\hline & $\begin{array}{l}\text { Corporate- } \\
\text { market }\end{array}$ & Network & Procedural & $\begin{array}{l}\text { Corporate- } \\
\text { market }\end{array}$ & Network & Procedural & $\begin{array}{l}\text { Corporate- } \\
\text { market }\end{array}$ & Network & Procedural \\
\hline $\begin{array}{l}\text { ground between the } \\
\text { needs of job seekers, } \\
\text { employers, and the } \\
\text { social security system }\end{array}$ & & & & & & & & & \\
\hline $\begin{array}{l}\text { 13. I use a lot of personal } \\
\text { judgement to decide } \\
\text { what is best for each } \\
\text { job seeker }\end{array}$ & & -.32 & & & .36 & & & .73 & \\
\hline $\begin{array}{l}\text { 14. Before reporting a job } \\
\text { seeker for non- } \\
\text { compliance, I would } \\
\text { always consider } \\
\text { which classification } \\
\text { group they belonged } \\
\text { to } \\
\end{array}$ & & & & .33 & & & .43 & & \\
\hline $\begin{array}{l}\text { 15. I like to keep my own } \\
\text { records and files on } \\
\text { job seekers and } \\
\text { programmes }\end{array}$ & & .36 & & & & -.43 & & .45 & \\
\hline $\begin{array}{l}\text { 16. Our computer system } \\
\text { tells me what steps to } \\
\text { take with job seekers } \\
\text { and when to take } \\
\text { them }\end{array}$ & & & .36 & .33 & & & & & .38 \\
\hline $\begin{array}{l}\text { 17. When you get a good } \\
\text { result with job } \\
\text { seekers it's usually a } \\
\text { team effort by }\end{array}$ & & & .37 & .31 & & .33 & & & \\
\hline
\end{tabular}




\begin{tabular}{|c|c|c|c|c|c|c|c|c|c|}
\hline & \multicolumn{3}{|c|}{$\begin{array}{c}\text { Australia } \\
\text { (24.5\% of variance explained) }\end{array}$} & \multicolumn{3}{|c|}{$\begin{array}{c}\text { The Netherlands } \\
\text { (23.0\% of variance explained) }\end{array}$} & \multicolumn{3}{|c|}{$\begin{array}{c}\text { UK } \\
\text { (27.2\% of variance explained) }\end{array}$} \\
\hline & $\begin{array}{l}\text { Corporate- } \\
\text { market }\end{array}$ & Network & Procedural & $\begin{array}{l}\text { Corporate- } \\
\text { market }\end{array}$ & Network & Procedural & $\begin{array}{l}\text { Corporate- } \\
\text { market }\end{array}$ & Network & Procedural \\
\hline $\begin{array}{l}\text { yourself, trainer, other } \\
\text { staff in your office, } \\
\text { and the employer }\end{array}$ & & & & & & & & & \\
\hline $\begin{array}{l}\text { 18. To get job seekers to } \\
\text { pay attention I often } \\
\text { remind them that } \\
\text { enforcing compliance } \\
\text { is part of my job }\end{array}$ & .49 & & & .55 & & & .38 & & \\
\hline $\begin{array}{l}\text { 19. My job is determined } \\
\text { by goals set } \\
\text { elsewhere }\end{array}$ & .53 & & & & .38 & & .65 & & \\
\hline $\begin{array}{l}\text { 20. More and more the } \\
\text { objective in this job is } \\
\text { to maximise the } \\
\text { organisation's } \\
\text { financial outcomes }\end{array}$ & .49 & -.49 & & & .64 & & .67 & & \\
\hline $\begin{array}{l}\text { 21. I think the objective } \\
\text { in this job is to shift } \\
\text { the maximum number } \\
\text { of job seekers off } \\
\text { benefits }\end{array}$ & .39 & -.49 & & .55 & & & .53 & & \\
\hline $\begin{array}{l}\text { 22. I use our information } \\
\text { technology system to } \\
\text { track priority job } \\
\text { seekers }\end{array}$ & & & .38 & .58 & & & & & .39 \\
\hline $\begin{array}{l}\text { 23. I do tend to take note } \\
\text { of those actions with } \\
\text { job seekers that will }\end{array}$ & & -.72 & & .46 & & & .32 & & .54 \\
\hline
\end{tabular}




\begin{tabular}{|c|c|c|c|c|c|c|c|c|c|}
\hline & \multicolumn{3}{|c|}{$\begin{array}{c}\text { Australia } \\
\text { (24.5\% of variance explained) }\end{array}$} & \multicolumn{3}{|c|}{$\begin{array}{c}\text { The Netherlands } \\
\text { (23.0\% of variance explained) }\end{array}$} & \multicolumn{3}{|c|}{$\begin{array}{c}\text { UK } \\
\text { (27.2\% of variance explained) }\end{array}$} \\
\hline & $\begin{array}{l}\text { Corporate- } \\
\text { market }\end{array}$ & Network & Procedural & $\begin{array}{l}\text { Corporate- } \\
\text { market }\end{array}$ & Network & Procedural & $\begin{array}{l}\text { Corporate- } \\
\text { market }\end{array}$ & Network & Procedural \\
\hline $\begin{array}{l}\text { generate a payable } \\
\text { outcome for the office }\end{array}$ & & & & & & & & & \\
\hline $\begin{array}{l}\text { 24. All my job seekers } \\
\text { receive a similar } \\
\text { service }\end{array}$ & & .33 & & & -.33 & & & .44 & \\
\hline $\begin{array}{l}\text { 25. I am often asked to } \\
\text { suggest ways to } \\
\text { improve things }\end{array}$ & & & .47 & & & & & & .47 \\
\hline $\begin{array}{l}\text { 26. I am aware that my } \\
\text { organisation pays } \\
\text { attention to the } \\
\text { income I generate by } \\
\text { placing job seekers }\end{array}$ & & & & & & & & & .49 \\
\hline $\begin{array}{l}\text { 27. If an official from } \\
\text { another employment } \\
\text { organisation asked for } \\
\text { help in using the } \\
\text { computer, I would } \\
\text { help them }\end{array}$ & & .51 & & & .39 & & & & \\
\hline $\begin{array}{l}\text { 28. In my job, job seekers } \\
\text { are organised into } \\
\text { formal and informal } \\
\text { priority groups }\end{array}$ & .38 & & & .46 & & & .50 & & \\
\hline
\end{tabular}

Note: In these tables, the factor loadings are from a principal components analysis using varimax rotation on the three factor solution. Only the factor loadings with a magnitude of 0.30 or more are shown, for ease of interpretation. 
Appendix 2: 2008 Factor Loadings for 3 Factor Solution

\begin{tabular}{|c|c|c|c|c|c|c|c|c|c|}
\hline & \multicolumn{3}{|c|}{$\begin{array}{c}\text { Australia } \\
\text { (24.5\% of variance explained) } \\
\end{array}$} & \multicolumn{3}{|c|}{$\begin{array}{c}\text { The Netherlands } \\
\text { (23.0\% of variance explained) }\end{array}$} & \multicolumn{3}{|c|}{$\begin{array}{c}\text { UK } \\
\text { (27.2\% of variance explained) }\end{array}$} \\
\hline & $\begin{array}{l}\text { Corporate- } \\
\text { market }\end{array}$ & Network & Procedural & $\begin{array}{l}\text { Corporate- } \\
\text { market }\end{array}$ & Network & Procedural & $\begin{array}{l}\text { Corporate- } \\
\text { market }\end{array}$ & Network & Procedural \\
\hline $\begin{array}{l}\text { 1. I find that issuing } \\
\text { Participation Reports } \\
\text { (sanctions) can really } \\
\text { damage your } \\
\text { reputation with job } \\
\text { seekers and others in } \\
\text { the employment field }\end{array}$ & & & & & & .44 & & .40 & \\
\hline $\begin{array}{l}\text { 2. The lines of authority } \\
\text { are not clear in my } \\
\text { work }\end{array}$ & & & -.45 & & & .47 & & & -.65 \\
\hline $\begin{array}{l}\text { 3. I do not like my } \\
\text { competition (internal } \\
\text { or external) to know } \\
\text { how I go about } \\
\text { getting my results }\end{array}$ & & & & & & .60 & & & -.44 \\
\hline $\begin{array}{l}\text { 4. My job can be done } \\
\text { by following a few } \\
\text { basic rules }\end{array}$ & & & & & & & & & \\
\hline $\begin{array}{l}\text { 5. When it comes to } \\
\text { day-to-day work I am } \\
\text { free to decide for } \\
\text { myself what I will do } \\
\text { with each job seeker }\end{array}$ & & .35 & & & .43 & & & .53 & \\
\hline
\end{tabular}




\begin{tabular}{|c|c|c|c|c|c|c|c|c|c|}
\hline & \multicolumn{3}{|c|}{$\begin{array}{c}\text { Australia } \\
\text { (24.5\% of variance explained) }\end{array}$} & \multicolumn{3}{|c|}{$\begin{array}{c}\text { The Netherlands } \\
\text { (23.0\% of variance explained) }\end{array}$} & \multicolumn{3}{|c|}{$\begin{array}{c}\text { UK } \\
\text { (27.2\% of variance explained) }\end{array}$} \\
\hline & $\begin{array}{l}\text { Corporate- } \\
\text { market }\end{array}$ & Network & Procedural & $\begin{array}{l}\text { Corporate- } \\
\text { market }\end{array}$ & Network & Procedural & $\begin{array}{l}\text { Corporate- } \\
\text { market }\end{array}$ & Network & Procedural \\
\hline $\begin{array}{l}\text { 6. My supervisor knows } \\
\text { a lot about the work I } \\
\text { do day-to-day }\end{array}$ & & & .62 & -.30 & .38 & & & .36 & .46 \\
\hline $\begin{array}{l}\text { 7. The really important } \\
\text { rules in this job are } \\
\text { the ones to do with } \\
\text { obtaining assistance } \\
\text { from other } \\
\text { organisations }\end{array}$ & & .54 & & & & .34 & & .48 & \\
\hline $\begin{array}{ll}\text { 8. } & \text { In my job, I am NOT } \\
\text { influenced by } \\
\text { numerical targets } \\
\text { (including star rating) }\end{array}$ & -.55 & & & -.50 & & & & & \\
\hline $\begin{array}{l}\text { 9. The main thing I have } \\
\text { to do in this job is } \\
\text { gain the trust of the } \\
\text { job seeker }\end{array}$ & & .60 & & & .52 & & & .47 & \\
\hline $\begin{array}{l}\text { 10. Our organisation has } \\
\text { targets for certain } \\
\text { types of job seekers }\end{array}$ & .45 & & & .35 & & & .38 & & \\
\hline $\begin{array}{l}\text { 11. When I come across } \\
\text { something not } \\
\text { covered by the } \\
\text { procedural guide, I } \\
\text { refer it to my } \\
\text { supervisor }\end{array}$ & & & .54 & & & .60 & & .38 & \\
\hline $\begin{array}{l}\text { 12. The goal in this work } \\
\text { is to find a middle }\end{array}$ & & .52 & & & .45 & & & .41 & \\
\hline
\end{tabular}




\begin{tabular}{|c|c|c|c|c|c|c|c|c|c|}
\hline & \multicolumn{3}{|c|}{$\begin{array}{c}\text { Australia } \\
\text { (24.5\% of variance explained) }\end{array}$} & \multicolumn{3}{|c|}{$\begin{array}{c}\text { The Netherlands } \\
\text { (23.0\% of variance explained) }\end{array}$} & \multicolumn{3}{|c|}{$\begin{array}{c}\text { UK } \\
\text { (27.2\% of variance explained })\end{array}$} \\
\hline & $\begin{array}{l}\text { Corporate- } \\
\text { market }\end{array}$ & Network & Procedural & $\begin{array}{l}\text { Corporate- } \\
\text { market }\end{array}$ & Network & Procedural & $\begin{array}{l}\text { Corporate- } \\
\text { market }\end{array}$ & Network & Procedural \\
\hline $\begin{array}{l}\text { ground between the } \\
\text { needs of job seekers, } \\
\text { employers, and the } \\
\text { social security system }\end{array}$ & & & & & & & & & \\
\hline $\begin{array}{l}\text { 13. I use a lot of personal } \\
\text { judgement to decide } \\
\text { what is best for each } \\
\text { job seeker }\end{array}$ & & .46 & & & .41 & & & .40 & \\
\hline $\begin{array}{l}\text { 14. Before reporting a job } \\
\text { seeker for non- } \\
\text { compliance, I would } \\
\text { always consider } \\
\text { which classification } \\
\text { group they belonged } \\
\text { to } \\
\end{array}$ & & .37 & & & & & & .47 & \\
\hline $\begin{array}{l}\text { 15. I like to keep my own } \\
\text { records and files on } \\
\text { job seekers and } \\
\text { programmes }\end{array}$ & & .44 & & & .31 & & & .41 & \\
\hline $\begin{array}{l}\text { 16. Our computer system } \\
\text { tells me what steps to } \\
\text { take with job seekers } \\
\text { and when to take } \\
\text { them }\end{array}$ & & & & & & & .38 & & \\
\hline $\begin{array}{l}\text { 17. When you get a good } \\
\text { result with job } \\
\text { seekers it's usually a } \\
\text { team effort by }\end{array}$ & & & .49 & & .46 & & & .43 & .34 \\
\hline
\end{tabular}




\begin{tabular}{|c|c|c|c|c|c|c|c|c|c|}
\hline & \multicolumn{3}{|c|}{$\begin{array}{c}\text { Australia } \\
\text { (24.5\% of variance explained) }\end{array}$} & \multicolumn{3}{|c|}{$\begin{array}{c}\text { The Netherlands } \\
\text { (23.0\% of variance explained) }\end{array}$} & \multicolumn{3}{|c|}{$\begin{array}{c}\text { UK } \\
\text { (27.2\% of variance explained) }\end{array}$} \\
\hline & $\begin{array}{l}\text { Corporate- } \\
\text { market }\end{array}$ & Network & Procedural & $\begin{array}{l}\text { Corporate- } \\
\text { market }\end{array}$ & Network & Procedural & $\begin{array}{l}\text { Corporate- } \\
\text { market }\end{array}$ & Network & Procedural \\
\hline $\begin{array}{l}\text { yourself, trainer, other } \\
\text { staff in your office, } \\
\text { and the employer }\end{array}$ & & & & & & & & & \\
\hline $\begin{array}{l}\text { 18. To get job seekers to } \\
\text { pay attention I often } \\
\text { remind them that } \\
\text { enforcing compliance } \\
\text { is part of my job }\end{array}$ & .35 & & .34 & & & & .55 & & \\
\hline $\begin{array}{l}\text { 19. My job is determined } \\
\text { by goals set } \\
\text { elsewhere }\end{array}$ & .44 & & & .46 & & & .60 & & \\
\hline $\begin{array}{l}\text { 20. More and more the } \\
\text { objective in this job is } \\
\text { to maximise the } \\
\text { organisation's } \\
\text { financial outcomes }\end{array}$ & .62 & & -.31 & .58 & & .32 & .50 & & -.44 \\
\hline $\begin{array}{l}\text { 21. I think the objective } \\
\text { in this job is to shift } \\
\text { the maximum number } \\
\text { of job seekers off } \\
\text { benefits }\end{array}$ & .49 & & & .32 & & & .62 & .53 & \\
\hline $\begin{array}{l}\text { 22. I use our information } \\
\text { technology system to } \\
\text { track priority job } \\
\text { seekers }\end{array}$ & .37 & & .31 & .40 & & & .50 & & \\
\hline $\begin{array}{l}\text { 23. I do tend to take note } \\
\text { of those actions with } \\
\text { job seekers that will }\end{array}$ & .58 & & & .50 & & & .37 & .40 & \\
\hline
\end{tabular}




\begin{tabular}{|c|c|c|c|c|c|c|c|c|c|}
\hline & \multicolumn{3}{|c|}{$\begin{array}{c}\text { Australia } \\
\text { (24.5\% of variance explained) }\end{array}$} & \multicolumn{3}{|c|}{$\begin{array}{c}\text { The Netherlands } \\
\text { (23.0\% of variance explained) }\end{array}$} & \multicolumn{3}{|c|}{$\begin{array}{c}\text { UK } \\
\text { (27.2\% of variance explained) }\end{array}$} \\
\hline & $\begin{array}{l}\text { Corporate- } \\
\text { market }\end{array}$ & Network & Procedural & $\begin{array}{l}\text { Corporate- } \\
\text { market }\end{array}$ & Network & Procedural & $\begin{array}{l}\text { Corporate- } \\
\text { market }\end{array}$ & Network & Procedural \\
\hline $\begin{array}{l}\text { generate a payable } \\
\text { outcome for the office }\end{array}$ & & & & & & & & & \\
\hline $\begin{array}{l}\text { 24. All my job seekers } \\
\text { receive a similar } \\
\text { service }\end{array}$ & & & & & .36 & & & & .42 \\
\hline $\begin{array}{l}\text { 25. I am often asked to } \\
\text { suggest ways to } \\
\text { improve things }\end{array}$ & & & .51 & & .47 & & & .49 & .39 \\
\hline $\begin{array}{l}\text { 26. I am aware that my } \\
\text { organisation pays } \\
\text { attention to the } \\
\text { income I generate by } \\
\text { placing job seekers }\end{array}$ & .53 & & & .37 & .32 & & & .56 & \\
\hline $\begin{array}{l}\text { 27. If an official from } \\
\text { another employment } \\
\text { organisation asked for } \\
\text { help in using the } \\
\text { computer, I would } \\
\text { help them }\end{array}$ & & .35 & & & & -.38 & & .39 & \\
\hline $\begin{array}{l}\text { 28. In my job, job seekers } \\
\text { are organised into } \\
\text { formal and informal } \\
\text { priority groups }\end{array}$ & .39 & & & & .43 & & .38 & & \\
\hline
\end{tabular}

